\title{
䫟骨に発生した多発性セメント質腫の 2 例
}

西嶋克已・石田利広・長畠駿一郎・岡本健一郎

綱島正和・洲脇貞吉・鶴田昭雄

\section{Multiple cementoma of the jaw bone: Report of two cases}

\author{
Katsumi Nishijima - Toshihiro Ishida - Shunichiro - Nagahata - Kenichiro OKamoto \\ Masakazu Tsunashima - Sadayoshi Suwaki - Akio Tsuruta
}

緒言

セメント質腫は中胚葉性崡原性腫場の 1 つで, 歯の発 育期に関係なく歯小㖶あるいは十分成熟した歯根膜より 発生し, 組織学的にはセメント質様硬組織の増殖を特徵 とする腫瘍である ${ }^{1,2)}$.

本腫瘍は一般に下䫇に，しかも単発性で無症状なもの が多く, エックス線撮影，2次的感染により偶然発見さ れる場合が多い3)

今回,われわれは多発性セメント質腫の 2 例を経験し, 症例 2 においては部位により異なるエックス線像, 病理 組織像のみられた稀有な症例を経験したので報告する.

症例

\section{症例 1}

患者 57歳 女性.

初 診: 昭和 45 年 7 月

主 訴: $\underline{65}$ 部の鈍痛扎よび排膿.

既往歴, 家族歴：特記事項なし。

現病歴 : 患者は16歳ごろより右側下顎骨体部の膨隆を 認めていたが，無痛性のため放置していた．昭和 28 年 4 月中旬, 農作業中に器械の鉄片にて右側煩部を打撲し, 以後右側煩部の疼痛と腫脹が持続したため, 同年 5 月

当歯科受診。多発性骨腫拈よび骨䯣炎の診断のもと に，右側下䫣臼歯部より下顎枝にわたり腫湯の一部を摘 出，自家助骨移植を施行，その後経過良好であった，昭 和45年 1 月ごろより右側煩部に有痛性腫脹をきたし，某 歯科にて洗浄などをらけていたが, 症状の軽快はみられ す，約 4 か月前某病院外科を受診し，右側上買臼歯部の 腐骨摘出術をらけた，以後腫脹はやや縮小したが，同部

岡山大学医学部口腔外科学教室（主任：西鸠克巳教 授）

Department of Oral Surgery, Okayama University Medical School (Chief: Prof. Katsumi Nishijima) 受付日：昭和52年 9 月 28 日
からの軽度の排膿と鈍痛が持続するため当口腔外科へ来 院した。

\section{現 症}

全身所見：体格・栄養状態ともに中等度で，骨格その ほかに異常所見は認められなかった。

口腔外所見 : 右側下顎角部から右側顎下部にわたり昭 和 28 年にうけた手術による瘢痕形成がみられ，下顎はや や右側に偏位し顔面非対称を呈していた．所属リンパ節 は左側顎下リンパ節大豆大 1 個を触知したが, 可動性で 圧痛は認められなかった。

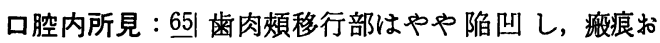
よび廈孔を形成し，排膿が認められた， $\frac{43}{43} \frac{34}{34}$ 部頓側およ び左側下顎大臼雨部煩・舌側に軽度の骨様膨隆が認めら れた（写真１）.

エックス線所見：上䫕骨は $2-1-2$ を除いた全域に 数個 の濃淡不整, 塊状の境界明膫なエックス線不透過像がみ られ，両側とも智歯が埋伏していた。顎骨は 4 部よ り左側下顎枝中央部まで広範囲に上䫑骨と同様の境界明 嘹なエックス線不透過像がみられ，右側下顎骨体部より 右側下顎枝にかけて昭和 28 年に施行された移植骨および 結禁線がみられた（写真 2，3）.

臨床検査所見: 一般血液検査, 血清化学検査は表 1 , 表 2 のごとくで, 白血球数の減少がみられた以外，心電 図, 胸部エックス線, 全身のエックス線写真などには異 常はみられなかった（表 1，2）。

臨床診断：多発性骨腫および 65| 部腐骨形成の疑い.

処置および経過：昭和 45 年 8 月 局所麻酔のもと に，腫瘍の一部ならびに腐骨摘出術を施行した。すなわ ち 7-3| 部の煩側歯肉を剥離すると，やや帯黄色で粗な 腐骨様のものが露出し, 容易に周囲より分離 摘出でき た。 また腫湯の一部を除去したのち，同部の歯慒骨整形 を施行した。同様に 134 部腫湟を部分切除した。ささらに $\overline{2-1-2}$ は辺縁性歯周炎にて抜霜した。 その後, 経過観 察していたが，昭和46年 1 月ごろより再度 65 部より軽 度の排膿と鈍痛をきたし持続したため，昭和46年11月 入院の上, 腐骨除去ならびに董場の一部摘出を行っ た.すなわち $7-3$ 部蒾肉を剝離すると, 前回同様帯黄 


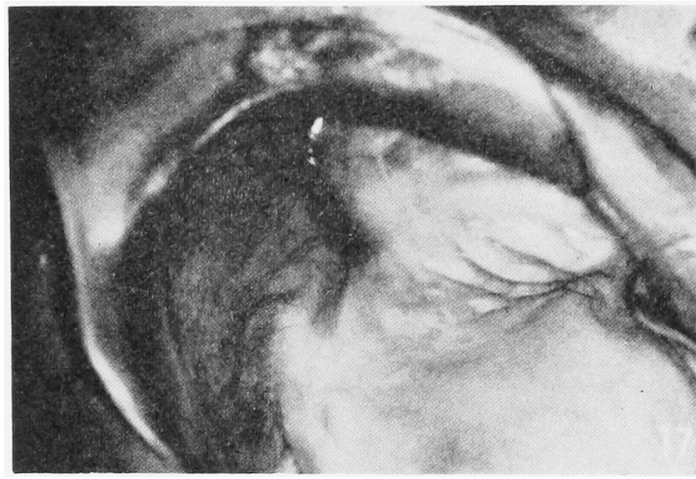

写真 1 症例 1 , 初診時口腔内： 765 部

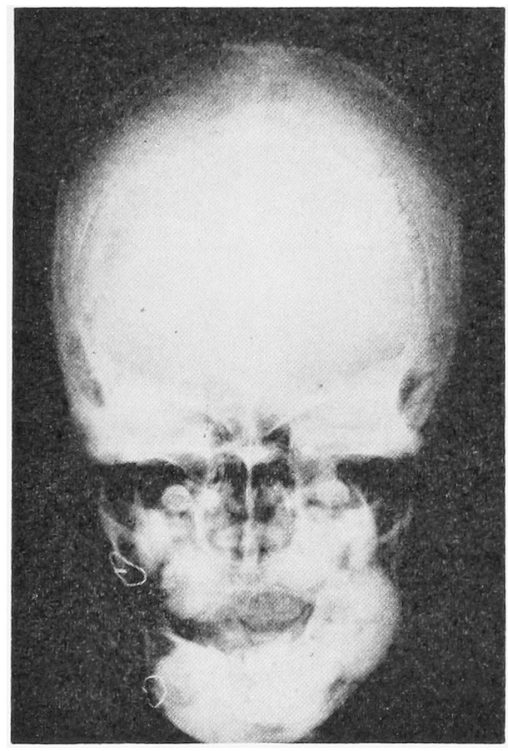

写真 2 初診時エックス線像

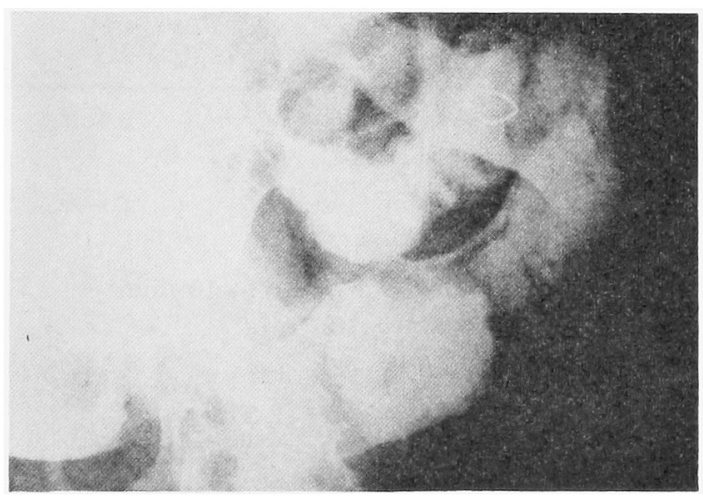

写真 3 初診時エックス線像

色の粗な腐骨様硬組織がみられた，65 部では周囲骨皮 質と容易に分離摘出できたが，１部では帯黃色，滑沢
表 1

\begin{aligned} \hline 一般血液検查 & \\ 1. 血色素量 & $11.5 \mathrm{~g} / \mathrm{d} l \\$ 2. 赤血球数 & $392 \times 10^{4} / \mathrm{m} \mathrm{m}^{3} \\$ 3. 色素指数 & 0.91 \\ 4. 白血球数 & $3,000 / \mathrm{m} \mathrm{m}^{3} \\$ 5. 出血時間 & 1.5 分 \\ 6. ヘマトクyット & $28.0 \%\end{aligned}$

表 2

\begin{tabular}{|c|c|}
\hline \multicolumn{2}{|l|}{ 血清検査 } \\
\hline \multicolumn{2}{|c|}{ ワッセルマン反応 (一) } \\
\hline 化学検查 & \\
\hline 1. $\mathrm{Fe}$ & $98 \mu \mathrm{g} / \mathrm{d} l$ \\
\hline 2. $\mathrm{Cu}$ & $100 \mu \mathrm{g} / \mathrm{d} l$ \\
\hline 3. $\mathrm{Na}$ & $138.5 \mathrm{mEq} / \mathrm{L}$ \\
\hline 4. $\mathrm{K}$ & $3.8 \mathrm{mEq} / \mathrm{L}$ \\
\hline 5. $\mathrm{Ca}$ & $9.8 \mathrm{mg} / \mathrm{d} l$ \\
\hline 6. $\mathrm{Al}-\mathrm{P}$-ase & 2. 0 B.L.u \\
\hline 7. 1) $\mathrm{GOT}$ & $15 \mathrm{u}$ \\
\hline 2) GPT & $6 \mathrm{u}$ \\
\hline
\end{tabular}

な硬固様であったため，破骨鉜子にて削除した。術後 5 年 9 か月を経た現在, 経過良好で排膿および腫煌の増大 傾向はみられない(写真 4 ).

摘出物所見：摘出した74334 部腫場はいずれも緻密な 骨様硬を呈しており，靑面滑沢であった，そのほかのも のは，帯黄色，粗な腐骨様組織であった。

病理組織学的所見: 大小不規則な融合性で遊離した, 淡紅色に平等に染まるセメント質よりなり，辺縁部のと ころどころに石灰沈着がみられた。この平等に染まる硬 組織は，部位によって多少細線維の集合よりなり，むた 全く無構造で平等にみられるところるあった，ところど ころ中に細胞を入れていない細胞窩がみられ，間質には 好中球を含を炎症性反応がみられた（写真 5 ).

病理組織診断：巨大型七メント質腫.

症例 2

患 者：【40歳 女性.

初 診: 昭和50年 8 月

主 訴: 17 部異和感。

既往歴：6 年前, 狭心症にて, 某病院に約 5 か月間入 院加療した。

家族歴：特記事項なし。

現病歴: 約 3 か月半前, 䠛蝕治療のため某歯科を受診 したところ，両側下顎目雨根端部のエックス線不透過像 を指摘され, 某病院海科にて $\overline{7}$ 拔雪後, 当科へ紹介さ れ来院した。 


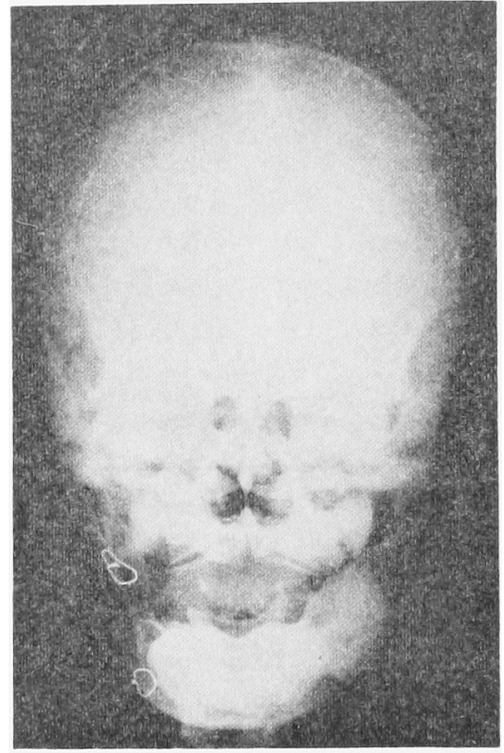

写真 4 这後エックス線像

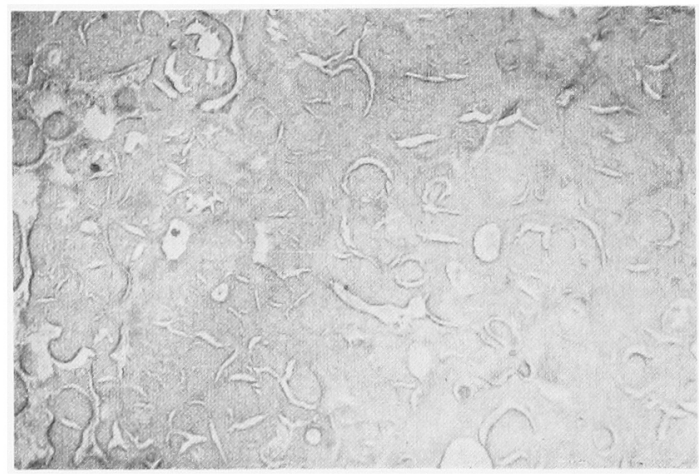

写真 5 病理組織像 H. E. 染色 $(\times 10)$

現 症

全身所見：体格中等度，栄盖状態良好，

口腔外所見：顔貌に異常なく, 所属リンパ節の腫脹, 圧痛も認められなかった。

口腔内所見 $\cdot \overline{7}$ 部煩側歯肉に轻度の圧痛を認めたが， ほかに異常を認めず，歯䯣電気診断においては $\frac{763-1-36}{8-\mid-5}$ 生活歯, $\frac{54 \mid 45}{16}$ 失活歯であった（写直 6).

エックス線所見 : $\frac{6}{7-2 \mid 5-7}$ 根端部に小豆大から掋指頭 大の比較的境界明膫なエックス線不透過像を認め，その 周囲には一部ェックス線透過像で囲まれた像がみられ た. $\frac{4 !}{1-1-24}$ 根端部には, やや境界不明膫な米粒大のエッ クス線透過像を認めた（写真 7，8）。

臨床検查所見：血液検查および血清化学検查は表了， 表 4 のごとくで，白血球数の娍少がみられた以外，特に 買常所見はみられず，また尿検查，血清蛋白あるいは内

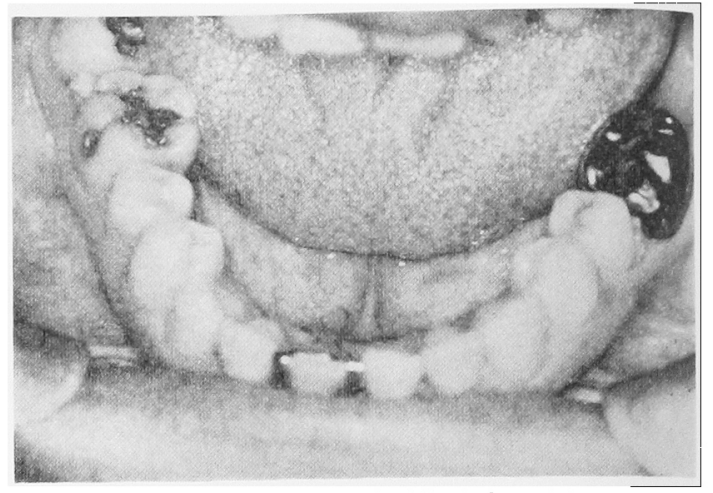

写真 6 症例 2 , 当科初診時口瑸内

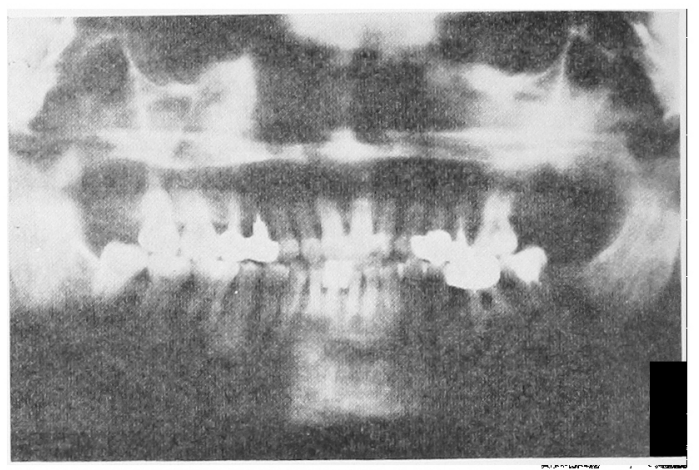

写真 7 某病院菌科初診時エックス線像

表 3

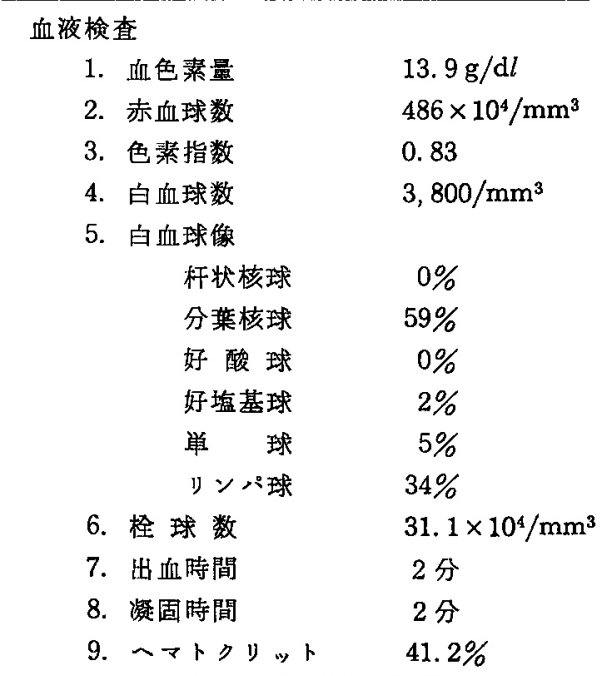

科的にも異常所見はみられなかった。 臨床診断： $64-24-7$ セメント質喠.

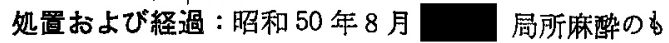
とに $\overline{7-5 \mid 6}$ 拔迷および 517 部腫瘍の部分切除施行. 病理 


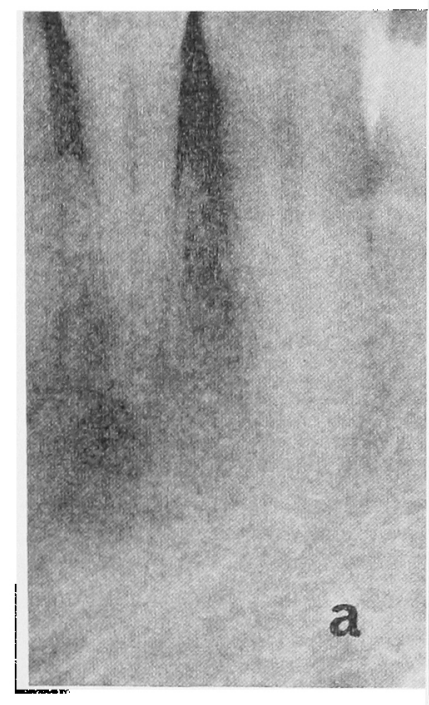

写真 8 当科初診時エックス線像 $a: \mid \overline{123}$ 部, $b: \mid \overline{67}$ 部, $c: \overline{543}$ 部

表 4

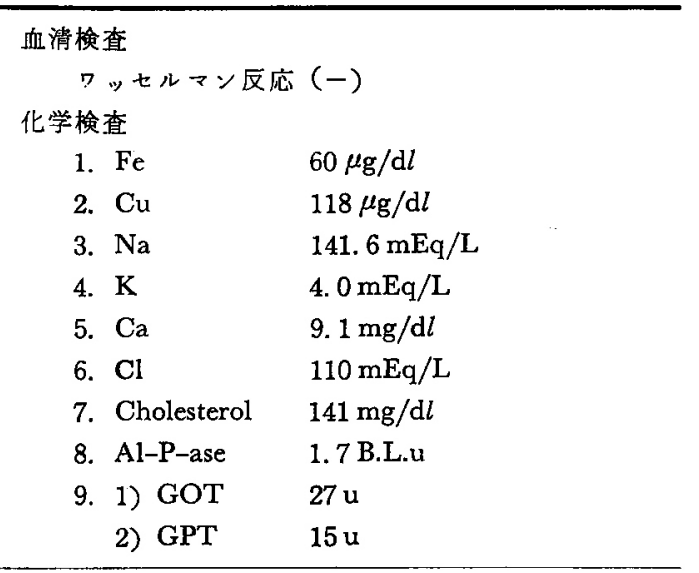

組織学的にセメント質尰と診断されたため，11月 全身麻酔の\&とに $\overline{7-2 \mid 5-7}$ 部腫瘍摘出， $\overline{43} \mid$ 崡根端切除

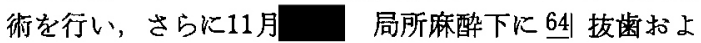

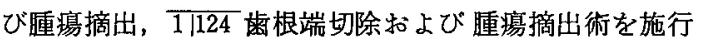
した。エックス線不透過像部に相当する瘇瘍は帯黄白 色, 骨様硬, 境界不明瞭であり, 一塊として摘出は困難 であったため，分割摘出を行った．エックス線透過像部 では帯赤灰白色で，一部に肉茅様の脆弱な部分もみられ た. 術後 1 年 9 か月を経た現在, 経過良好で再発など異 常所見は認められない（写真 9).

\section{病理組織学的所見 :}

|7部; 腫湟は楾䌖腫性組織とセメント質よりなり， 線維尰性組織の中にセメント質形成がすすみ，互いに融 合乙增大していく硬組織が主体を占めていた，以上の所 見より，根端性セメント質異形成症と診断された（写真 


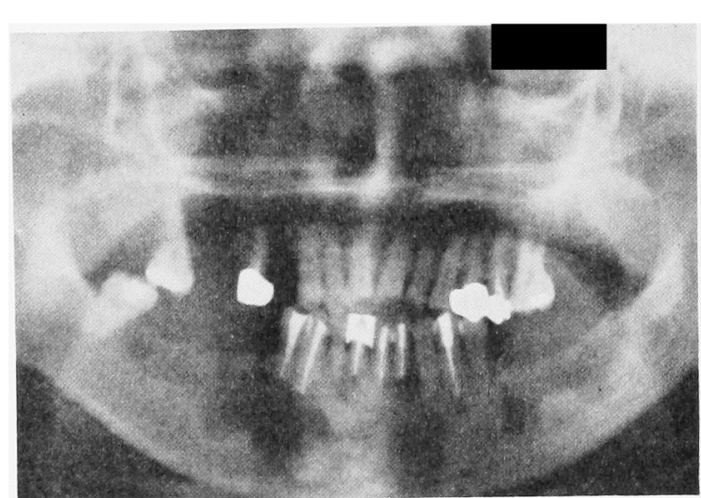

写真 9 術後エックス線像

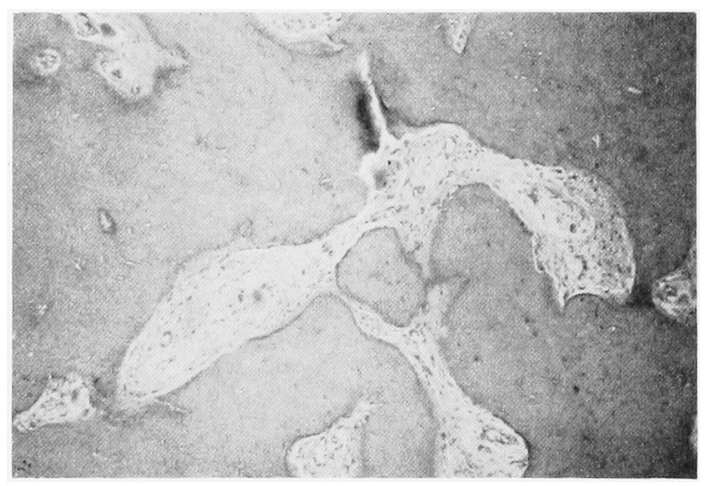

写真 $10 \mid 7$ 部病理組織像 H. E. 染色 $(\times 40)$

10).

$\sqrt{2}$ 部; 線維腫性組織が主体を占め, その中に H.E. 染 色に好染する硬組織の形成がみられ，拡大像に括いて， 紡鍾形の細胞の中に同心円状の細胞封入を欠くセメント 粒の形成がみられた。 以上の所見より，根端性セメント 質異形成症と診断された（写真11-a, b).

51 部; 腫瘍組織はェオシンン好染するセメント質の 増殖よりなり，ところどころに類円形ないし不整形の比 較的狭い間質が散在性にみられ, その周囲を層状のへマ トキシリンに染まる石灰化線が取り巻き，なたほぼ平等 に染まる基質には，わずかに線維状の錯走した構造がう かがわれ，その中に封入細胞を欠く空虚な小窩が散見さ れた，以上の所見より，巨大型セメント質腫とした（写 真 12$)$.

またエェックス線的に根端部に同様の像がみられた 6) 部は $\sqrt{7}$ 部と，奋| 部は $\sqrt{2}$ 部と病理組織学的に同様の 所見がみられた。

考察

セメント質腫の発生機序に関 し, Thoma \& Gold$\operatorname{man}^{1)}(1960)$ は，大部分の絭原性腫济は齿の発有段階で

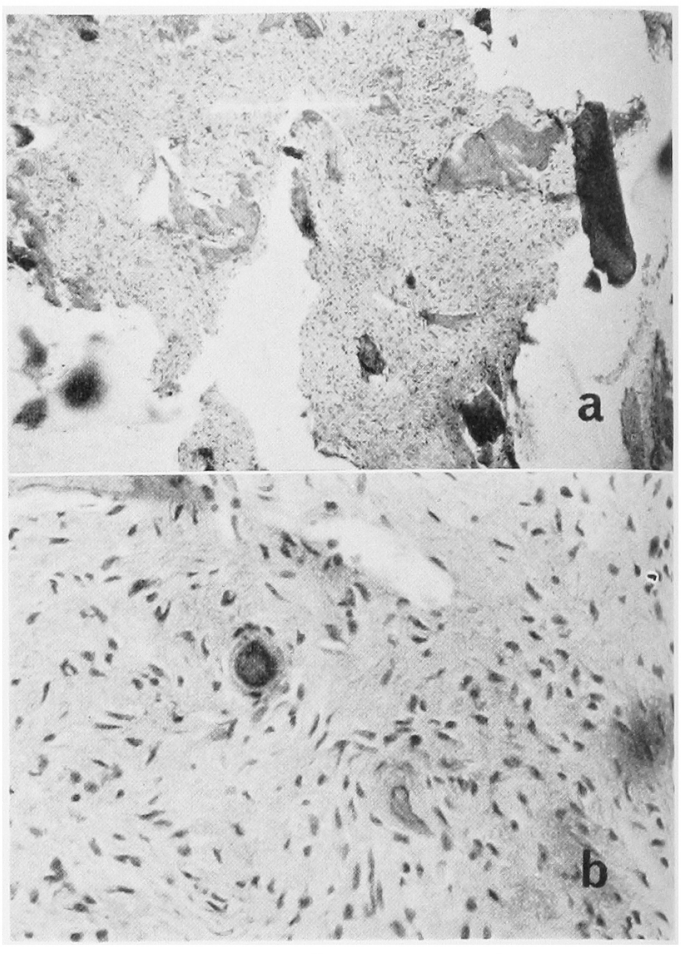

写真 $11 \sqrt{2}$ 部病理組織像

H. E. 染色 a : $(\times 40)$, b : $(\times 100)$

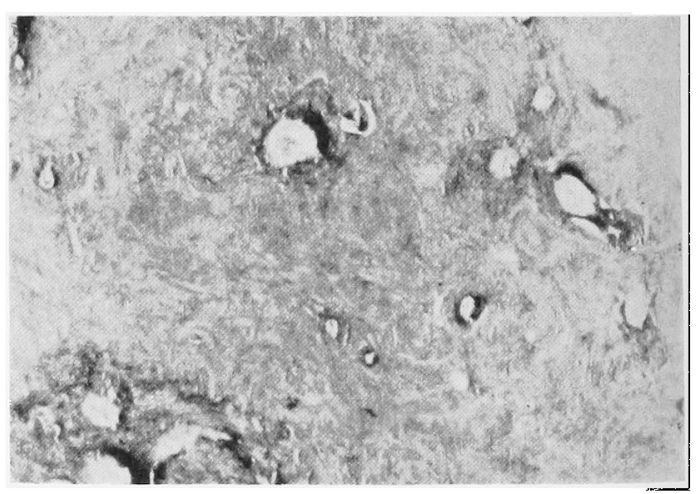

写真 $12 \overline{5}$ 部病理組織像 H. E. 染色 $(\times 40)$

形成されるのに対し，七メント空腫は正常に発育した谏 小要の根端部あるいは成熟した雪の雪根膜より発生する と述べている，発生の由来について，Kline ら4)(1961) は雪小栾あるいは歯根膜のどちらより生ずるかは明確て ないと述べ，Stafne な $^{5}$ (1975) は，大部分は齿根膜飞由 来すると述ぺている.

発生原因については種々の説がある，すなわち，Scannel1 ${ }^{6}$ （1949）は炎症性反応，外傷，軽度の感染症，内 分泌異常，ビタミン欠乏，全身的疾患をあげている. Zegarelli ら) (1964) は，230人の本疾患の統計で明磪 
な系統的疾患は発見できなかったが，女性が 215 人と大 多数を占めていたことから，なにか内分泌との関係が考 えられると述べている，本症例において子臨床諸検査， 四肢長管骨, 胸部, 骨艋などのエックス線撮影などを施 行したが，いずれも特に異常を認めず，明確な原因と考 えられる疾患は認められなかったが，性別については 2 症例とも女性であった。

次に発育過程についてみると，本腫媓は一般的に組織 学的には歯根膜の結合組織の増殖よりなり，根端に接し た種々の大きさの線維性結合組織塊を形成する．Stafnes) は, この段階ではセメント粒類似の円形ないし卵 形の少量の石灰化物がこの線維性結合組織の中にみら れ, さらに発育すると, (1) 一定期間Periapical fibroma あるいは Cementoblastoma としてとどまる。(2) セ人 ント質類似の石灰化組織に変わる。（3）まれな例として 正常骨に置換される．以上の 3 経過をとる可能性がある と述べている。

Thoma \& Goldman 1) はセメント質腫を発育の過程 により，組織学的，エックス線的所見より 3 段階に分け ている。すなわち，最初の段階を Osteolytic stage とよ び，未成熟な時期でをだ石灰化組織を含まず細胞成分に 富む線維芽細胞, 膠原線維, 少数の血管よりなり, 幼若 な宩根膜に似た構造をもつとし，エックス線的には透過 像を示す. 第 2 の段階として, この組織の中にセメント 粒が形成され，大きさと数を增し，互いに癒合し石灰化 組織を形成する。この段階を Cementoblastic stage と よび, エックス線的には一部不透過像を示し, 未石灰化 組織はエックス線透過像を示す。発育の最終段階を Mature inactive stage とよび, 病巣は大部分石灰化組 織塊で占められ，周囲を細いェックス線透過像により取 り团をれた像を示すと述べている。

症例 1 では，上買骨および下罘骨とも腫湯と考えられ る部分は境界明瞭なエックス線不透過像を示し, 組織学 的には線維性結合組織はもはやみられず，大小不規則 な融合性の硬組織のみがみられたことより， Mature inactive stage と考えられた.

症例 $2: \overline{1-1-2}$ 根端部においては，いずれも生活歯であ ったが，境界不明瞭な米粒大のエックス線透過像がみら れ, 組織学的にはセメント粒の形成, 大小不整の硬組織 がみられたことより，Cementoblastic stage と考えられ た（写真 8-a, 11）、| 7 部においては, 病巣の中心は小 指頭大のエックス線透過像により取り囲まれていた。組 織学的にはセメント質形成がすすみ，互いに融合し硬組 織が主体を占めていたことより, 病理学的には第 2 の段 階と推察されたが，全体的にみるとむしろ最後の段階に 近いと考劣られた（写真 8-b，10）. 5 | 部においては, 董瘍全体が高度に石灰化したセメント質の增殖よりな り，エックス線では不透過性であり，最終段階であると 考えられた（写真 8-c，12）.
セメント質腫は現在, 病理組織学的には，(1) 良性セ メント芽細胞腫，(2) 根端性セメント質異形成症，(3) セメント質形成線維腫，（4）巨大型セメント質腫に分類 されている2,8).

根端性セメント質異形成症はセメント質形成線維腫と 鑑別を要するが，セメント質形成線維腫について，黑柳 ら ${ }^{9)}$ (1973) は細胞成分に富む線維腫内に円形ないし類 円形のセメント質粒ないしセメント質の小塊が散在し, 腫痬が大きくなってもセメント質塊の大きさは変化しな いと述べている。

症例 1 においては，顎骨にほぼ同様のエックス線不透 過像がみられ, 経過も長く, 腫湟の発育はほほ終了して いると考えられたが，症例 2 においては，同一䫇骨内に 組織学的に異なるセメント質腫がみられた。 Thoma \& Goldman ${ }^{11}$ の分類より推察すると, 発育途中の段階之考 えられるものもあったが，これらが最終的にどのような 臨床症状, エックス線像および組織像を示すかは推定の 域をでない。

石川・秋吉 ${ }^{2}$ は，セメント質腫は病理像の多様性から, 必ずしも各型を明確に区別できない場合もありらると述 べ, 本腫瑒の大きさについて，一部にはかなりの大きさ まで増大し，㴿骨を膨隆させると述べている，症例 1 で は，腫瑒は上顎骨および下㴿骨のほぼ全域にわたり，一 部には䫁骨の膨隆がみられた。

巨大な本腫湯の報告をみると, 清水ら ${ }^{10)}$ (1969) は20 数年にわたる経過を観察し，右側上罰洞を満たすほどに 発育した症例を報告, 伊藤ら ${ }^{11)}(1974)$ は下買骨骨体部 に広範な裂胞を伴って増大した巨大な症例を報告してい る。

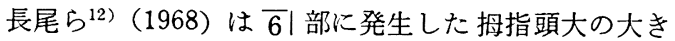
さで，その下部は下䫇管に接し下歯槽神経を圧迫，鈍痛 を生ぜしめていた症例を報告している.

本腫湯の上下顎における発生頻度についてみると, Scannell') は $1: 5$, Kline $5^{4)}$ は $1: 15$, Zegarelli7) は $1: 14.3$ で，いずれも下顎に多く，性別では女性に多く みられたと報告している。本邦における多発性セメント 質腫についての報告例は比較的少ない13 15) が， Thoma \& Goldman 1), Lucas ${ }^{3)}$ はまれでないと述べている.

セメント質腫と他疾患との鑑別について, Stafne ${ }^{5)}$ は セメント質腫の最初の段階においては, 根端部にェック ス線透過像として現われるため, 歯の色および歯髄生活 反応が正常であり，歯髄炎あるいは外傷の既往歴がない 場合には，かなり確実に診断できると述べている。 Thoma \& Goldman ${ }^{1)}$ は発育の第 2 段階においてセメン 卜質増殖症との鑑別について，七メント質腫は根端との 間に歯根膜が介在するが, セメント質増殖症では介在し ないと述べている。また Cementoblastoma を取り团む 骨が一般に街密なのは皮質板形成によるとし，覇胞の周 囲にみられるものと同様であるとしている。 
骨疾患との鑑別について, Stafne ${ }^{5)}$ は石灰化したセメ ント質腫は, エックス線透過像により周囲を取り囲まれ て拉り, 正常骨組織より分けられていることより, osteosclerosis, condensing osteitis, あるいは endostosis など と鑑別できると述べている，一方，Fullmer ${ }^{16)}(1967) は ，$ 歯根膜はセメント質，歯槽骨执よび線維性組織形成能力 をもつ blastic cell を含むと述べ, Hamner ら ${ }^{17)}$ (1968) は病的状態のもとでは, 歯根膜はセメント質, 層板骨, 線維性組織あるいはこれらの 3 組織がいくつか混合した 腫瘍, すなわち cementifying fibroma, ossifying fibroma, cemento-ossifying fibroma を生じうると述べてい る。われわれの第 1 症例においては顔貌の変形がみられ たが，これらの所見はみられなかった。

\section{結 語}

57歳および40歳女性の上下顎に多発したセメント質腫 の 2 例を経験した。

症例 1 では, 腫瘍は上下顎ほぼ全域に存在し, 一部に は顎骨の膨隆がみられた。

症例 2 では, 同一顎骨内に拈いて, 部位により X 線 像, 病理組織像が異なった症例であった。

稿を終わるに臨み病理組織学的に御教示いただいた本 学第 2 病理学教室元井 信講師に感謝の意を表します.

本論文の要旨は昭和 50 年 6 月, 第 4 回日本口腔外科学 会中国四国兵庫地方会扣よび昭和 51 年 5 月, 第30回日本 口腔科学会総会に打いて発表した。

\section{文献}

1) Thoma, K.H. and Goldman, H.M.: Oral Pathology. ed 5, Mosby Co, St Louis, 1960, p 1203.
2) 石川梧朗, 秋吉正豊 : 口腔病理学 II. 增補版, 永末書店, 京都, 1971，948頁.

3) Lucas, R.B.: Pathology of Tumors of the Oral Tissues. ed 2, J. \& A. Churchill, London, 1972, p 96.

4) Kline, S.N., et al.: Large cementoma of the mandible. OS OM OP 14: 14211961.

5) Stafne, E.C.: Oral Roentgenographic Diagnosis. ed 4, W.B. Saunders, Philadelphia 1975, p 183.

6) Scannell, J.M.: Cementoma. OS OM OP 2: 11691949.

7) Zegarelli, E.V., et al.: The cementoma; a study of 230 patients with 435 cementomas. OS OM OP 17: 2191964.

8) Gorlin, R.J. and Goldman, H.M.: Thoma's Oral Pathology I. ed 6, Mosby Co, St Louis, 1970, p 503.

9）黒楖錦也, 他: Cementifying fibroma の 3 症 例. 口科誌 22: 6331973.

10）清水和幸，他：長期の程過をとった上䫑洞内七 メントームの 1 治験例. 口科誌 18:764 1969.

11）伊藤輝夫, 他：弯胞を伴った巨大な Cementoma と, その顎骨切除後の即時再建について. 日口外誌 20：469 1974.

12）長尾喜景，他：下顎骨に発生した Cementoma の 1 例. 歯科学報 68: 12451968.

13）藤岡幸雄, 他: 上下顎に発生した Multiple cementomaの 1 例(抄). 日口外誌 14: 1981968.

14）佐藤伊吉，他：顎骨に多発したセメント質腫の 2 例（抄). 日口外誌 16:244 1970 .

15）岸本 源，他：全顎に発生した Gigantiform Cementoma の 1 症例。 日口外誌 22:875 1976.

16) Fullmer, H.M.: 17 より引用.

17) Hamner, J.E., et al.: Cemento-ossifying fibroma of the maxilla. OS OM OP 26: 587 1968. 